\title{
RECENT ADVANCES IN PULSED ELECTRIC FIELD AND NON-THERMAL PLASMA TREATMENTS FOR FOOD AND BIOREFINERY APPLICATIONS
}

\section{NAJNOVIJA DOSTIGNUĆA U TRETMANIMA HRANE I BIORAFINERIJSKIM POSTUPCIMA PULSNIM ELEKTRIČNIM POLJEM I NETERMALNOM PLAZMOM}

\author{
Aleksandra ĐUKIĆ-VUKOVIĆ* , Urszula TYLEWICZ ${ }^{* *}$, Ljiljana MOJOVIĆ ${ }^{*}$, Christian GUSBETH ${ }^{* * *}$ \\ *University of Belgrade, Faculty of Technology and Metallurgy,11120 Belgrade, Karnegijeva 4, Serbia \\ ** University of Bologna, Department of Agricultural and Food Sciences, Piazza Goidanich 60, 47521 Cesena, Italy \\ ${ }^{* * *}$ Karlsruhe Institute of Technology (KIT), Institute for Pulsed Power and Microwave Technology, Hermann-von-Helmholtz-Platz 1, \\ 76344 Eggenstein-Leopoldshafen, Germany \\ e-mail: adjukic@tmf.bg.ac.rs
}

\begin{abstract}
In the last decays pulsed electric field techniques gained increasing importance in biotechnology and food production. Application of electric pulses to cells leads to increased permeability and conductivity of cell membranes and formation of pores in cell membrane - phenomenon called electroporation. Electroporation could be a very suitable technique for improvement of extraction or dying in both food processing and biorefinery.

Non-thermal plasma treatment generates reactive species in the samples causing damage of the cell membrane and could be used for wastewater treatment, microbial inactivation and as a treatment prior to open fermentations on complex substrates.

In this study, recent advances in pulsed electric field treatment of food, algal biomass and hospital wastewater as well as role of non-thermal plasma treatment in bio-decontamination of complex substrates will be addressed. Also, some environmental and economic aspects of these novel techniques in comparison to conventional treatments will be discussed.
\end{abstract}

Key words: pulsed electric field, non-thermal plasma, food processing, wastewater, microalgae, microbial inactivation.

\section{REZIME}

U toku poslednjih nekoliko decenija tretman pulsnim električnim poljem dobija sve više na značaju u oblasti biotehnologije $i$ proizvodnje hrane. Izlaganjem humanih, biljnih ili mikrobnih ćelija pulsnom električnom polju povećava se pemeabilnost $i$ provodljivost ćelijske membrane što vodi stvaranju pora u membrani, pa se ovaj fenomen naziva elektroporacija. Elektroporacija može biti veoma korisna tehnika za unapređenje ekstrakcije ili sušenja u oblasti proizvodnje i prerade hrane (ekstrakcija šećera iz šećerne repe, unapređenje osmotskog sušenja, sušenja smrzavanjem itd.), ali $i$ u biorafinerijskim postupcima poput ekstrakcije vrednih supstanci iz mikroalgi, iskorišćenja otpadnih voda, ekstrakcije iz biljne biomase, itd.Kao rezultat tretmana netermalnom plazmom nastaju slobodni radikali u uzorku koji dovode do oštećenja ćelija, uključujući ćelijske membrane, smanjenjuje se pH vrednost u medijumu, a UV zračenje izvora plazme može dodatno uticati na mikrobnu inaktivaciju u tretiranom uzorku. Zato se tretman netermalnom plazmom može efiksno koristiti za sterilizaciju površina $i$ mikrobnu inaktivaciju $u$ voćnim sokovima $u$ prehrambenoj industriji, biodekontaminaciju složenih otpadnih supstrata ili mikrobnu inaktivaciju u otpadnim vodama kako bi se unapredili postupci otvorene fermentacije. U ovom radu su detaljnije predstavljene mogućnosti ptimene pulsnog električnog polja u tretmanu hrane, ektrakciji mikroalgi i smanjenju problema širenja multirezistentnih bakterija iz otpadnih voda iz bolnica. Takođe, analizirane su neke mogućnosti primene tretmana netermalnom plazmom u biodekontaminaciji otpadnih voda, kao i ekonomski $i$ ekološki aspekti ovih novih tehnika u odnosu na konvencionalne postupke.

Ključne reči: pulsno električno polje, netermalna plazma, prerada hrane, otpadne vode, mikroalge, mikrobna inaktivacija.

\section{INTRODUCTION}

Application of electric pulses to human, bacterial or plant cells causes, under adequate conditions, increase in permeability and conductivity of cell membranes and hence formation of aqueous pores in the membranes. This phenomenon of pore formation in membranes as a result of pulsed electric field (PEF) treatment is called electroporation (Rems and Miklavčič, 2016). The electroporation results in losing of the barrier function of bio-membranes and subsequently in a molecular exchange between cytoplasm and external medium across the lipid membrane. Depending on conditions of treatment, the electric field intensity and the exposure time, a reversible or an irreversible membrane permeabilization can be induced (Neumann and Rosenheck, 1972). The rate of cell membrane permeabilization as a result of electroporation strongly depends on the electric field intensity and the total time of treatment, but also on the diameter and other characteristics of the cells and cell arrangement, e.g. tissue or suspension. Therefore, electroporation could be a very suitable technique for improvement of extraction, including extraction of colorants from red beet (Loginova et al., 2011), antioxidants (Puertolas et al., 2012) and for extracting lipids for biodiesel from oilproducing microalgae (Goettel et al., 2013; Eing et al., 2013) as well as proteins (Haber-Meglič et al., 2016) or as an alternative for already established drying techniques (Stamenković et al., 2015; Radojčin et al., 2013). Also, since 1980s, electroporation was used for transfection and exchange of genes between cells for biotechnological applications (Neumann et al., 1982; Takahashi et al., 2015), introduction of drugs into the cells for medicinal applications like electrochemoterapy (Miklavčič et al., 2014) or irreversible electroporation for tumor ablation (AlSakere et al., 2007). Shorter treatment time, often lower energy input, lower consumption of chemicals, higher extract yields as well as stimulation of metabolism observed in some plants (Mahnic-Kalamiza et al., 2014) are some of the advantages of PEF treatment over conventional processing techniques which facilitates current high research interest and application of PEF treatment on industrial scale.

Plasma is defined as a neutral ionized gas, while non-thermal plasmas are type of plasmas generated at lower pressures and temperatures than thermal plasmas and these are less energy intensive. Non-thermal plasma treatment causes generation of 
reactive species as a result of interaction between ions from plasma source and treated media which positions plasma treatments as physico-chemical methods while PEF treatment is considered physical treatment (Graves, 2012). As a result of non-thermal plasma treatment oxidation of organic compounds and decrease in $\mathrm{pH}$ value of media are occurring, leading to degradation of organic dyes (Attri et al., 2016), organic pollutants (Bansode et al., 2017), inactivation of microorganisms present in aqueous solution (Puač et al., 2015) and juices (Herceg et al., 2015) or for biodecontamination of effluents (Doubla et al., 2007) and increase of roughness of solid particles present in treated media (Wu et al. 1995; Krásný et al. 2014).

The versatility of effects as a result of PEF and plasma treatment enables wide application range of these methods both in food and biorefinery processes. In this paper, the selected recent advances in the applications of PEF and non-thermal plasma in food processing and biorefinery processes will be addressed and current trends will be highlighted.

\section{MATERIAL AND METHOD}

The detailed survey of the literature through scientific search engines like ScienceDirect, Scopus and Google Scholar was performed. Different relevant keywords were used, including „pulsed electric field“, „non-thermal plasma“, „food non-thermal plasma“, „biorefinery non-thermal plasma“, „biorefinery pulsed electric field“. Based on the listed references, more in-depth assessment of literature and expertise of authors the most relevant publications were further analyzed and discussed. compartments, thus resulting in changes in tissue material properties. In fact, several studies reported the changes in texture and color parameters of different plant tissues subjected to the PEF processing, which could consequently affect the final product quality characteristics. Usually, the changes in textural behavior (softening), related to PEF treatment are caused by a loss of turgor pressure of plant tissue (e.g. potato, tomato, sugar beet and carrot). Consequently, the handling, peeling pumping or cutting processes could be facilitated (Toepfl et al., 2012).

Aganovic et al. (2017) showed, that despite higher energy requirements for preservation of tomato and watermelon juice using PEF technology (around $0.12 \mathrm{kWh} / \mathrm{l}$ of juice) in comparison to the thermal process (around $0.04 \mathrm{kWh} / \mathrm{l}$ of juice), its advantage is widely recognized in its potential to deliver products with an improved quality compared to its thermal counterparts. The important issue in case of the industrial application is the adoption of Hazard Analysis and Critical Control Point (HACCP) and hazard and operability study concepts to control the process parameter. In fact, PEF preservation is a HACCP critical control point and requires consistent delivery and recording of sufficient treatment intensity. Usually, the parameters as: required energy delivery, frequency, pulse width and shape at the desired treatment temperature need to be elaborated in laboratory-scale challenge tests for each food product. At industrial level, the required energy delivery is often ensured by continuous monitoring of power delivery, which could be validated by measurement of the increase of food product temperature (Buckow et al., 2013).

\section{RESULTS AND DISCUSSION}

\section{PEF treatment in food processing}

PEF is a non-thermal technology, which has been introduced in the last years as an alternative to conventional food-processing methods. The reversible electroporation (the created pores reseal immediately after removing the electrical field) could be used to incorporate different functional substances into the vegetal tissue, assuring the survival of the electrically stimulated cells. Higher intensities of PEF, promote, instead, the irreversible tissue permeabilization (permanent membrane damage) and consequently the cell death (Toepfl et al., 2014).

In the last years, the use of PEF technology for food processing has been widely studied. It offers several advantages i.e. improvement of extraction process, enhancement of mass transport phenomena and inactivation of enzymes and microorganisms, offering an attractive alternative to traditional mechanical, thermal or chemical methods.

Table 1. PEF-assisted processing of biological tissue.

\begin{tabular}{|c|c|c|}
\hline Process & $\begin{array}{c}\text { PEF effects vs conventional } \\
\text { treatment }\end{array}$ & Reference \\
\hline $\begin{array}{c}\text { Osmotic } \\
\text { dehydration }\end{array}$ & $\begin{array}{c}\text { improvement of mass } \\
\text { transfer (higher water loss) }\end{array}$ & $\begin{array}{c}\text { Traffano-Schiffo et al. } \\
\text { (2016) }\end{array}$ \\
\hline Drying & $\begin{array}{l}\text { reduction of the drying time and } \\
\text { saving energy }\end{array}$ & Wiktor et al (2013) \\
\hline Freeze-drying & $\begin{array}{c}\text { reduction of the initial freezing } \\
\text { temperature and freezable water } \\
\text { content in the rehydrated plant } \\
\text { tissue; increase in the rehydration } \\
\text { capacity }\end{array}$ & $\begin{array}{l}\text { Tylewicz et al. (2016) } \\
\text { Esthiaghi et al. (1994) }\end{array}$ \\
\hline Freezing & $\begin{array}{c}\text { reduction of freezing time; } \\
\text { improvement of freezing tolerance } \\
\text { if combined with cryoprotectants } \\
\text { infusion }\end{array}$ & $\begin{array}{l}\text { Jalté et al. (2009) } \\
\text { Phoon et al. (2008) }\end{array}$ \\
\hline Extraction & $\begin{array}{c}\text { higher rate of extraction of } \\
\text { bio-active compounds; increased } \\
\text { yield of juice production }\end{array}$ & $\begin{array}{l}\text { Luengo et al.(2013) } \\
\text { Bazhal and Vorobiev } \\
\text { (2000) }\end{array}$ \\
\hline
\end{tabular}

Therefore, the potentiality of the PEF applications in the food industry is very huge and it has been revised by Barba et al. (2015).

For liquid food processing, high intensity PEF has been used as an alternative to traditional thermal pasteurization, and it is named cold pasteurization. It has been proven that PEF treatment of milk, juices and juice blends reduced the microbial growth in the similar range of thermal pasteurization treatment (Sharma et al., 2014; Sampedro et al., 2013). The advantages of this technology are represented in higher retention of bio-active compounds, fresh-like sensorial attributes, leading to obtain high nutritional quality products (Barba et al., 2015). Low/medium electric field strength PEF is aimed to disintegrate the biological tissue and Table 1 . reports its main application in food processing. PEF promotes the structural changes on a cellular level and water redistribution between different cellular

\section{PEF treatment in green technologies}

As a pure physical treatment method, the PEF treatment exhibits many advantages over conventional processing in various applications. As for instance, PEF treatment enables the inactivation of bacterial load in wastewater without adding harmful chemicals, the extraction of valuable substances from plant cells with low energy demand at low heat influx, and the separation and simultaneous recovery of lipids and water-soluble compounds at low-energy demand during downstream processing of algal biomass. PEF technology was proven for feasibility on pilot and industrial scale for large mass-flow application in energy technology, environmental technology and biotechnology (Kotnik et al., 2015; Pulz et al., 2004; Schultheiss et al., 2001). In addition PEF treatment enables the recovery of essential nutrients from plants and microorganisms, with higher purity, when compared with thermal, chemical and enzymatic methods, which usually affect the biological matter. The selected 
applications of PEF processing in green technologies will be discussed in more details in the following subsections.

\section{PEF assisted microalgae processing and extraction}

Microalgae are very fast growing organisms, which convert the light and carbon source in biomass, providing a biomass rich in valuable cell components, such as lipids, proteins, polysaccharides, antioxidants, and pigments (Rosello-Sastre et al., 2012). The main issue of using algae as an alternative and renewable source of biomass is the designing of an optimum cultivation system, involving enhancing the biology of the algal strain used and integrating it with the best suited downstream processing options (Jacobi and Posten, 2013). A medium-term energetic use of microalgae can only become economic, if additional valuable products are commercialized. Especially for realizing this so-called cascade processing of microalgae, PEF treatment offers promising options for energy-efficient microalgae downstream processing.

Recently, it could be show that PEF treatment $(40 \mathrm{kV} / \mathrm{cm})$ in a continuous flow cell applied to microalgae Auxenochlorella protothecoides suspension results in a significant increase of the lipid yield (Eing et al., 2013; Goettel et al., 2013). At specific treatment energy of $150 \mathrm{~kJ}$ per kg suspension, the lipid yield, extracted with the environmental-friendly solvent ethanol, was on average, four times higher when compared with untreated samples. Moreover, recovery of proteins and carotenoids from chlorella could be increased by $27 \%$ and $52 \%$, respectively using PEF. This study primarily indicates that PEF-assisted extraction is highly selective and allows the release of soluble intracellular matter. On the other hand, it shows that extraction of lipids required the application of solvents. Some studies claim the use of PEF-treatment at the first step of extraction and the solvents at the second step of extraction. However, industrial processing plants extract soyabean oil by solvent liquid transfer using hexane (Garcia Serrato, 1981), followed by subsequent proteins extraction from defatted soybean meal. PEF-treatment method might improve this processing, since it allows the wet processing of algal biomass, while more than $80 \%$ of the stored lipids can be recovered by green solvent extraction. It could be also shown that PEF treatment of microalgae also results in significant increase of the yield of fatty acids (Sheng et al., 2011). Thus a series of costly procedures such as drying and cell breaking can be saved, resulting in significantly lower environmental impact of overall process.

Microbial decontamination of hospital wastewater by means of PEF treatment

Hospital wastewater becomes in the last decades a significant source of dissemination of resistance genes in aquatic systems, due to the fact that these are loaded with antibiotic multiresistant pathogens (Rieder et al., 2008; Schwartz et al., 2003; Volkmann et al., 2007). In appropriate milieu these microorganism are able to proliferate to high density, which conduct to blow out of a large variety of resistance genes and the genetic exchange. Therefore, one major objective is a sustainable protection of water resources which can be done on the one hand, by enhancing the overall medical care and hygiene and, on the other hand, by preventing the dissemination of resistant bacteria.

The majority of the conventional water disinfection methods are known from water purification plants. Applied disinfection techniques have demonstrated disadvantages like generation of toxic disinfection by-products (DBP) during chemical disinfection or reduced efficiency in liquids with high turbidity in case of UV radiation (Emmanuel et al., 2004; Jungfer et al., 2007).

The main benefit of PEF treatment of hospital wastewater derives from the fact that there is no generation of systemic DBP or similar harmful chemical during and after treatment. The fluid is disinfected on-site in the PEF-treatment zone, and there is no prolonged effect such as in case of chlorination. From the high number of studies performed over decades we know that PEF treatment can be used for processing liquid and semiliquid (mash-like) food products with low electrical conductivity $(<4$ $\mathrm{mS} / \mathrm{cm}$ ), but also for drinking water and wastewater.

\section{Performance of PEF processing in hospital wastewater} treatment

In principle for the evaluation of the PEF performance for microbial decontamination of wastewater the parameters used for food processing serve as a reference for performing inactivation studies. The main parameters under investigation are electric field amplitude, $\mathrm{E}\left(5-100 \mathrm{kVcm}^{-1}\right)$, pulse duration, $\mathrm{t}$ $(0.2-100 \mu \mathrm{s})$, and specific energy, which can be adjusted by the number of pulses, $\mathrm{N}$. The pulse shape (rectangular, exponentially decaying, unipolar, or bipolar) and the frequency play a minor role in improving the inactivation performance. Bipolar pulse protocols are proven to be advantageous for pulsed electric field processing in general since it decreases electrochemical erosion of treatment electrodes (Frey et al., 2013; Kotnik et al., 2001). Summarized, it could be claimed that the inactivation performance of PEF treatment is not directly proportional to a specific energy input and the results obtained from processing hospital wastewater and liquid food are similar (Frey et al., 2013). The inactivation kinetics deviates from the first-order kinetics, and it seems that the bacterial inactivation saturates at around $6 \log$ reduction (Gusbeth et al., 2009a; Wouters et al., 2001). Furthermore, within a pulse duration range of 100-10 $\mu$ s and at invariable suspension conductivity, inactivation does not depend on pulse duration in case the external field amplitude is high enough to provide fast membrane charging at the entire cell surface. The dissipated energy and bacterial reduction follow a dose-response relationship, and the inactivation rate scales with the specific energy $\left(\sim \mathrm{Et}^{2}\right)$.

Gram-negative bacteria, such as Escherichia coli or Pseudomonas aeruginosa are much more sensitive to electric field treatment than Gram-positive bacteria, such as Staphylococcus aureus or Enterococcus faecium, as could be shown for PEF treatments with specific energies ranging from 80 to $190 \mathrm{Jml}^{-1}$ (Frey et al, 2013; Gusbeth et al., 2009a; Gusbeth et al., 2009b). Bacterial inactivation efficiency of up to 5.5 decimal orders of magnitude was obtained for Gram-negative reference strains, such as $P$. aeruginosa, when treated with specific energies exceeding $150 \mathrm{Jml}^{-1}$. In contrast, inactivation experiments on different $E$. faecium strains showed wide variance of the inactivation efficiency. In different independent experiments, different reduction patterns were observed. Inactivation experiments on wastewater containing mixed bacterial populations reveal that the most robust bacteria strain dominates the resulting inactivation rate of the wastewater sample. At standard treatment conditions, $120 \mathrm{Jml}^{-1}$, the inactivation rate varied between 1.5 and $3.4 \log$ (Frey et al., 2013; Gusbeth et al., 2009a; Gusbeth et al., 2009b; Rieder et al., 2008).

\section{Sustainability of PEF disinfection method}

Two important issues have been investigated in order to confirm the sustainability of PEF method for disinfection of hospital wastewater: (i) bacteria do not adapt to electric field treatment (induction of electro-tolerant bacteria) and (ii) PEF treatment does not generate genotoxic by-products due to the electrolytic reaction of the wastewater compounds. Induced electro-tolerance in reference bacteria (Pseudomonas putida) was tested by consecutive treatment of survived bacteria, over 30 cycles (Gusbeth et al., 2009a; Rieder et al., 2008). Thus, an enrichment of bacterial population with electro-tolerant bacteria after PEF treatment as well as the transmission of electrotolerance from bacteria to bacterial descendants was not observed. In order to evaluate genotoxicity of PEF treated hospital wastewater, studies performed with SOS chromo test 
and Salmonella fluctuation test show that PEF treatments with specific treatment energies of more than $250 \mathrm{Jml}^{-1}$ did not change the hospital wastewater genotoxicity (Gusbeth et al., 2009a; Rieder et al., 2008). Also PEF treatments of phosphate buffer and domestic water with more than $480 \mathrm{~J} \cdot \mathrm{ml}^{-1}$ generated no genotoxic by-products.

\section{Economic feasibility of combining PEF with thermal} treatment

One drawback of the PEF treatment method is the high energetic demand (120 and $240 \mathrm{Jml}^{-1}$ ), required in order to achieve satisfactory bacterial inactivation ( $>4 \mathrm{log})$. This dissipated energy is enough to increase the fluid temperature by about $30-60 \mathrm{~K}$, if adiabatic conditions are applied. Under this circumstance, the combination of thermal and PEF treatment might be economically. It was shown that a combined treatment with PEF $\left(120 \mathrm{Jml}^{-1}\right)$ and heating increases bacterial inactivation rate of E. faecium significantly, from $2 \log$ at $25{ }^{\circ} \mathrm{C}$ to a complete bacterial inactivation at $60{ }^{\circ} \mathrm{C}$ (Gusbeth et al., 2009b). On the other hand at treatment temperatures below $55^{\circ} \mathrm{C}$, the combined treatment does not improve the inactivation rate. The effectiveness of the combined thermal and electric wastewater treatment was demonstrated on a prototype plant. Using heat exchangers for preheating and heat recovery, a disinfection of 4 5 log could be achieved with PEF-treatment energy of $40 \mathrm{Jml}^{-1}$. Under this premise, the PEF processing costs of $\$ 0.10 \mathrm{l}^{-1}$ can be drastically reduced, resulting in a competitive price compared to conventional disinfection methods (Gaudreau et al., 2006).

\section{Non-thermal plasma in food and biorefinery processes}

Non-thermal plasma could be a suitable solution for decontamination of sensitive surfaces and it is studied for different biomedical, food and environmental applications. It has been used in food industry (surface decontamination, microbial inactivation in liquid and solid food etc.) or for environmental purposes (decolourization, biodecontamination, waste gas treatment etc.). Characteristics of plasmas as well as effectiveness of the plasma treatments are influenced by carrier gas and experimental setup, and beside the effect of reactive species generated during treatment, reduction in the number of microorganisms is partially result of UV radiation of generated in plasma jet (Moreau et al., 2008; Babić Ljiljana, 2014). The effectiveness of non-thermal plasma treatment for microbial inactivation is highly influenced by the growth phase of microorganism, being more effective towards vegetative forms of microorganism (Moreau et al., 2008), similar as for PEF treatment (Haber-Meglič et al., 2016). The non-thermal plasma treatment was studied as a technique for microbial inactivation of juices (Herceg et al., 2015), but the studies on microbial inactivation by non-thermal plasma treatment in food matrixes with higher dry matter content are scarce. Challenges in application of plasma treatment are related to equipment design, scale up of processes, monitoring of degradation products and maintenance of treatment uniformity. The reproducibility of the treatment is strongly influenced by substrate composition and physical characteristics.

The application of non-thermal plasma treatment for microbial inactivation in wastewater and by-products of agrofood industry could be a promising strategy if this treatment could decrease a number of undesirable indigenous microbiota present is these rich media. Similarly to application of ultrasound (Đukić-Vuković et al., 2016; Tylewicz et al., 2013) and pulsed electric field treatment discussed in previous sections, nonthermal plasma could be used for improvement of biorefinery processes. Non-thermal plasma could be used as low energy pretreatment for physical decomposition/surface disruption of biomass and, as a consequence, easier attack by enzymes in saccharification (Benoit et al., 2012), or facilitated fermentative production of different chemicals (Briens et al., 2008), including hydrogen production (Holladay et al., 2009). In the case of lactic acid fermentation of stillage, a complex by-product of bioethanol production on different feedstocks, non-thermal plasma treatment could decrease the number of viable lactic acid bacteria up to $4 \mathrm{log}$, after $30 \mathrm{~min}$ treatment (unpublished data). This reduction in the number of microorganisms could be obtained with significantly lower energy imput in comparison to ultrasound treatment or thermal sterilization methods. This is a very important advantage of non-thermal plasma treatment because in many biorefinery processes on complex substrates, like stillage, a reduction of 3-4 log units is sufficient for further open fermentation by selected desired microorganism.

\section{CONCLUSIONS}

PEF treatment became very effective in bacteria inactivation, especially in combination with thermal treatment. Although sometimes higher in energy demand in comparison to conventional techniques it often provides products with higher quality, shorter production time and better overall characteristics. PEF could be a very suitable technique for various processing steps in food industry (drying, osmotic dehydration, extraction, freeze-drying) or for effective treatment for bio-decontamination of hospital wastewaters and for processing of microalgae for both biofuel production or for extraction of valuable nutraceuticals and pharmaceuticals. Nonthermal plasma treatment as a technique which has some similarities with the effects of PEF treatment on the cell level and cell permeabilization is also a promising technique for food and biorefinery processes. Non-thermal plasma could significantly decrease number of undesirable microorganisms on surfaces as well as in liquids (juices, wastewater, cell suspensions), degrade organic components (dyes, pesticides) and modify surfaces, including polymers and biomass components. The development of the equipment and better understanding of the basic principles behind both PEF and non-thermal plasma will enable wider and more efficient applications in future.

ACKNOWLEDGMENT: The work on this paper was performed as part of the project "Integrated pulsed electric field extraction and lactic acid bacteria fermentation for the production of micro algal extracts fortified with probiotics (PEF4AlgBiotics)" financed by The Serbian Ministry of Education, Science and Technological Development and The German Academic Exchange Service (DAAD).

\section{REFERENCES}

Aganovic, K., Smetana, S., Grauwet, T., Toepfl, S., Mathys, A., Van Loey, A., Heinz, V. (2017). Pilot scale thermal and alternative pasteurization of tomato and watermelon juice: An energy comparison and life cycle assessment. Journal of Cleaner Production, 141, 514-525.

Al-Sakere, B., André, F., Bernat, C., Connault, E., Opolon, P., Davalos, R.V., Rubinsky, B., Mir, L.M. (2007). Tumor ablation with irreversible electroporation. PloS one, 2 (11) e1135.

Attri, P., Yusupov, M., Park, J.H., Lingamdinne, L.P., Koduru, J.R., Shiratani, M., Choi, E.H., Bogaerts, A., (2016). Mechanism and comparison of needle-type non-thermal direct and indirect atmospheric pressure plasma jets on the degradation of dyes. Scientific Reports, 6, 34419.

Babić, Ljiljana (2014). Plasma application for biomaterials processing. Journal on Processing and Energy in Agriculture, 18 (3), 95-99.

Bansode, A.S., More, S.E., Siddiqui, E.A., Satpute, S., Ahmad, A., Bhoraskar, S.V., Mathe, V.L. (2017). Effective degradation of organic water pollutants by atmospheric non-thermal plasma torch and analysis of degradation process. Chemosphere, 167, 396-405.

Barba, F.J., Parniakov, O., Pereira, S.A., Wiktor, A., Grimi, N., Boussetta, N., Saraiva, J., Raso, J., Martin-Belloso, Olga, 
Witrowa-Rajchert, D., Lebovka, N., Vorobiev, E. (2015). Current applications and new opportunities for the use of pulsed electric fields in food science and industry. Food Research International, 77 (4), 773-798.

Bazhal, M., Vorobiev, E. (2000). Electrical treatment of apple cossettes for intensifying juice processing. Journal of the Science of Food and Agriculture, 80, 1668-1674.

Benoit, M., Rodrigues, A., Vigier, K.D.O., Fourré, E., Barrault, J., Tatibouët, J.M., Jérôme, F. (2012). Combination of ballmilling and non-thermal atmospheric plasma as physical treatments for the saccharification of microcrystalline cellulose. Green Chemistry, 14 (8), 2212-2215.

Briens, C., Piskorz, J., Berruti, F. (2008). Biomass valorization for fuel and chemicals production--A review. International Journal of Chemical Reactor Engineering, 6 (1).

Buckow, R., Ng, S., Toepfl, S. (2013). Pulsed electric field processing of orange juice: a review on microbial, enzymatic, nutritional, and sensory quality and stability. Comprehensive Reviews in Food Science and Food Safety, 12(5), 455-467.

Doubla, A., Laminsi, S., Nzali, S., Njoyim, E., Kamsu-Kom, J., Brisset, J.L. (2007). Organic pollutants abatement and biodecontamination of brewery effluents by a non-thermal quenched plasma at atmospheric pressure. Chemosphere, 69 (2), 332-337.

Đukić-Vuković, Aleksandra, Mladenović, Dragana, Jovanović, Jelena, Knežević-Jugović, Zorica, Kocić-Tanackov, Sunčica, Pejin, Jelena, Mojović, Ljiljana (2016). Ultrasound as a physical treatment of stillage for lactic acid fermentation. Journal on Processing and Energy in Agriculture, 20 (1), 13-16.

Eing, C., Goettel, M., Straessner, R., Gusbeth, C., Frey, W. (2013). Pulsed electric field treatment of microalgae benefits for microalgae biomass processing. IEEE Transactions on Plasma Science, 41 (10), 2901-2907.

Emmanuel, E., Keck, G., Blanchard, J.M., Vermande, P., Perrodin, Y. (2004). Toxicological effects of disinfections using sodium hypochlorite on aquatic organisms and its contribution to AOX formation in hospital wastewater. Environment international, 30 (7), 891-900.

Eshtiaghi, M.N., Stute, R., Knorr, D. (1994). High pressure and freezing pretreatment effects on drying, rehydration, texture and color of green beans, carrots and potatoes. Journal of Food Science, 59 (1168), 1170.

Frey, W., Gusbeth, C., Schwartz, T. (2013). Inactivation of Pseudomonas putida by pulsed electric field treatment: a study on the correlation of treatment parameters and inactivation efficiency in the short-pulse range. The Journal of membrane biology, 246 (10), 769-81.

Garcia Serrato, A. (1981). Extraction of oil from soybeans. Journal of the American Oil Chemists' Society, 58 (3), 157.

Gaudreau, M., Hawkey, T., Kempkes, M., Petry, J. (2006). Scaleup of PEF Systems for Food and Waste Streams. Proceedings of the 3rd Innovative Food Centre Conference, Bedford, MA.

Goettel, M., Eing, C., Gusbeth, C., Straessner, R., Frey, W. (2013). Pulsed electric field assisted extraction of intracellular valuables from microalgae. Algal Research, 2 (4), 401-408.

Graves, D. B. (2012). The emerging role of reactive oxygen and nitrogen species in redox biology and some implications for plasma applications to medicine and biology. Journal of Physics D: Applied Physics, 45 (26), 263001.

Gusbeth, C., Frey, W., Schwartz, T., Rieder, A. (2009b). Critical comparison between the pulsed electric field and thermal decontamination methods of hospital wastewater. Acta Physica Polonica-Series A General Physics, 115, 1092-1094.

Gusbeth, C., Frey, W., Volkmann, H., Schwartz, T., Bluhm, H. (2009a). Pulsed electric field treatment for bacteria reduction and its impact on hospital wastewater. Chemosphere, 75, 22833.

Haberl-Meglič, Saša, Levičnik, E., Luengo, E., Raso, J., Miklavčič, D. (2016). The effect of temperature and bacterial growth phase on protein extraction by means of electroporation. Bioelectrochemistry, 112, 77-82.

Herceg, Z., Režek Jambrak, Anet, Vukušić, T., Stulić, V., Stanzer, D., Milošević, S. (2015). The effect of high-power ultrasound and gas phase plasma treatment on Aspergillus spp. and Penicillium spp. count in pure culture. Journal of applied microbiology, 118 (1), 132-141.

Holladay, J.D., Hu, J., King, D.L., Wang, Y. (2009). An overview of hydrogen production technologies. Catalysis today, 139 (4), 244-260.

Jacobi, A., Posten, C. (2013). Energy considerations of photobioreactors. Algae for Biofuels and Energy, Springer, Dordrecht/Heidelberg/New York/London 5, 223-232.

Jalté, M., Lanoisellé, J.-L., Lebovka, N.I., Vorobiev, E. (2009). Freezing of potato tissue pre-treated by pulsed electric fields. LWT - Food Science and Technology, 42, 576-580.

Jungfer, C., Schwartz, T., Obst, U. (2007). UV-induced dark repair mechanisms in bacteria associated with drinking water. Water research, 41,188-196.

Kotnik, T., Frey, W., Sack, M., Meglič, S. H., Peterka, M., Miklavčič, D. (2015). Electroporation-based applications in biotechnology. Trends in biotechnology, 33 (8), 480-488.

Kotnik, T., Miklavčič, D., Mir, L.M. (2001).Cell membrane electropermeabilization by symmetrical bipolar rectangular pulses: part II. Reduced electrolytic contamination. Bioelectrochemistry, 54, 91-95.

Krásný, I., Lapčík, L., Lapčíková, B., Greenwood, R.W., Šafáŕová, K., Rowson, N.A. (2014). The effect of low temperature air plasma treatment on physico-chemical properties of kaolinite/polyethylene composites. Composites Part B: Engineering, 59, 293-299.

Loginova, K.V., Lebovka, N.I., Vorobiev, E. (2011). Pulsed electric field assisted aqueous extraction of colorants from red beet. Journal of Food Engineering, 106 (2), 127-133.

Luengo, E., Álvarez, I., Raso, J. (2013). Improving the pressing extraction of polyphenols of orange peel by pulsed electric fields. Innovative Food Science and Emerging Technologies, 17, 79-84.

Mahnič-Kalamiza, S., Vorobiev, E., Miklavčič, D. (2014). Electroporation in food processing and biorefinery. The Journal of membrane biology, 247 (12), 1279-1304.

Miklavčič, D., Mali, B., Kos, B., Heller, R., Serša, G. (2014). Electrochemotherapy: from the drawing board into medical practice. Biomedical engineering online, 13 (1), 29.

Moreau, M., Orange, N., Feuilloley, M.G.J. (2008). Non-thermal plasma technologies: new tools for biodecontamination. Biotechnology advances, 26 (6), 610-617.

Neumann, E., Rosenheck, K. (1972). Permeability changes induced by electricimpulses in vesicular membranes. The Journal of membrane biology, 14, 194-196.

Neumann, E., Schaefer-Ridder, M., Wang, Y., Hofschneider, P.H. (1982). Gene transfer into mouse lyoma cells by electroporation in high electric fields. The EMBO journal, 1 (7), 841.

Pulz, O., Gross, W. (2004).Valuable products from biotechnology of microalgae. Applied Microbiology and Biotechnology, 65 (6), 635-648.

Schultheiss, C., Bluhm, H., Mayer, H.G. (2001). Processing of sugar beets with pulsed electric fields. $2^{\text {nd }}$ Symp. Nonthermal/Medical/Biological Treatments using Electromagnetic Fields and Ionized Gases, Portsmouth, Va., May 21-23.

Received: 12.03.2017. 